\title{
Danish fisheries and aquaculture: past, present and future
}

Skov, Christian; Berg, Søren; Eigaard, Ole Ritzau; Jessen, Troels Kjeldbjerg; Skov, Peter Vilhelm

Published in:

Fisheries

Link to article, DOI:

10.1002/fsh.10330

Publication date:

2020

Document Version

Peer reviewed version

Link back to DTU Orbit

Citation (APA):

Skov, C., Berg, S., Eigaard, O. R., Jessen, T. K., \& Skov, P. V. (2020). Danish fisheries and aquaculture: past, present and future. Fisheries, 45(1), 33-41. https://doi.org/10.1002/fsh.10330

\section{General rights}

Copyright and moral rights for the publications made accessible in the public portal are retained by the authors and/or other copyright owners and it is a condition of accessing publications that users recognise and abide by the legal requirements associated with these rights.

- Users may download and print one copy of any publication from the public portal for the purpose of private study or research.

- You may not further distribute the material or use it for any profit-making activity or commercial gain

- You may freely distribute the URL identifying the publication in the public portal

If you believe that this document breaches copyright please contact us providing details, and we will remove access to the work immediately and investigate your claim. 
Article type : Feature

\section{Danish fisheries and aquaculture: past, present and future}

Christian Skov | DTU AQUA, Section of Inland Fisheries and Ecology, Technical University of Denmark, Vejlsøvej 39, 8600 Silkeborg, Denmark. Email: ck@aqua.dtu.dk

Søren Berg | DTU AQUA, Section of Inland Fisheries and Ecology, Technical University of Denmark, Vejlsøvej, Silkeborg, Denmark

Ole Ritzau Eigaard | DTU AQUA, Section for Ecosystem based Fisheries Management, Technical University of Denmark, Kemitorvet. Lyngby, Denmark

Troels Kjeldbert Jessen | DTU AQUA, Section for Monitoring and Data, Technical University of Denmark, Kemitorvet, Lyngby, Denmark

Peter Skov | DTU AQUA, Section for Aquaculture, Technical University of Denmark, North Sea Science Park, Hirtshals, Denmark

\section{ABSTRACT}

Denmark has long fisheries and aquaculture traditions. Today, the marine commercial fishery has three major fleet categories with respect to the type of target species: (1) fisheries for industrial fish species, (2) fisheries for pelagic human consumption fish species, and (3) fisheries for demersal human consumption fish and shellfish species. Recreational fisheries are widespread and dominated by angling, but also include net gear fishing and spearfishing. A mandatory national license system for recreational fishers has been in place since 1987, which finances research as well as management initiatives such as stocking and habitat restoration, the latter especially in relation to streams. Written evidence of aquaculture in Denmark dates back to 1241. Presently, production is dominated by land-based facilities producing Rainbow Trout Oncorhynchus mykiss. Here we present a short review of the history of these three sectors, including examples of cultural importance, as well as their current state and future perspectives.

This article has been accepted for publication and undergone full peer review but has not been through the copyediting, typesetting, pagination and proofreading process, which may lead to differences between this version and the Version of Record. Please cite this article as doi: 10.1002/fsh.10330

This article is protected by copyright. All rights reserved. 


\section{INTRODUCTON}

Denmark is almost completely surrounded by water, from the western mainland (Jutland), to its easternmost point (Christians $\varnothing$ ) in the central Baltic Sea. Despite its small size $\left(42,924 \mathrm{~km}^{2}\right)$, the numerous peninsulas and islands provides Denmark with $7314 \mathrm{~km}$ of coastline, one of the longest in Europe. Moreover, approximately $64,000 \mathrm{~km}$ of streams and rivers, connect some of the 120,000 lakes and ponds $\left(>100 \mathrm{~m}^{2}\right)$ found in the country. Together these marine, estuarine, and freshwater habitats constitute a firm foundation for production and exploitation of aquatic resources, in the form of fishing and aquaculture. Not surprisingly, Denmark has been a fishing nation since ancient times (e.g., Enghoff et al. 2007), and ranks among the 20 largest exporters of fish and fish products in the world, and in some years even among the top 10 (e.g., FAO 2011). Aquaculture has been practiced in Denmark for almost 800 years and today the Danish secondary industries for aquaculture (e.g., feed manufacture and recirculation technology) are world-renowned. As in many developed countries, fishing for recreational purposes has increased in popularity over the past century, and today constitutes an important leisure activity for a large part of the population. This review aims to describe the current state of Danish fisheries and aquaculture including major historical developments and examples of cultural importance, as well as briefly touching upon future perspectives.

\section{AQUACULTURE}

The first mention of aquaculture in Denmark occurs in the Provincial Law of Jutland from 1241. A passage stating that "no man is allowed to divert the water supply of another man's fishpond," signifies that sustenance fish farming occurred early in history. Exploitation of water bodies flourished in the Middle Ages, and lakes and ponds were used for cultivation of fish and crustaceans. Aquaculture initially became established at convents, castles, and manors, producing Crucian Carp Carassius carassius and Tench Tinca tinca, presumably due to their robustness and ease

This article is protected by copyright. All rights reserved. 
of reproduction, but also European Perch Perca fluviatilis, Common Bream Abramis brama and European Eel Anguilla anguilla. From 1560, Common Carp Cyprinus carpio was also cultivated on the grounds of Frederiksborg Castle and the convent in Gisselfeld. The fish master at Frederiksborg Castle was under contract to deliver 22 tons of fish annually from freshwater fisheries and aquaculture, to the royal family, in addition to deliveries to the commoners (Hoffmann and Bregnballe, 2018).

The first earthen pond for Rainbow Trout Oncorhynchus mykiss production in Denmark was excavated in 1894. By 1906, the Ministry of Agriculture decided to provide financial support for eight experimental aquaculture facilities in central Jutland and already by 1913 there were 138 trout farms. A number of technical notes and opinions on trout culture were published during the 1800s, and in 1905 a manual on trout farming in ponds was published (Madsen 1905). During each World War in the 20th century, the industry more or less collapsed, followed by a reestablishment during peace times.

For many years, the production of trout took place in large ponds, under extensive culture conditions with only a few fish per square meter of pond surface area, and little feed input, primarily as wet feed (fish offal). It was not until the 1980s that the implementation of water treatment technology began, and the production of extruded feeds, ultimately allowed for higher fish rearing densities. The initial development of water treatment to allow for recirculation was driven primarily by eel farmers to conserve heat for the successful warm water culture of European Eel. Today there is a small but consistent aquaculture production in Denmark, with some 43,000 tons of fish, and 2,200 tons of mussels produced in 2016. Presently, land-based facilities of different types dominate the production. Many of these are still traditional low technology pond culture (131 facilities), while some have adopted the Danish Model Trout Farm (MTF) concept (35 facilities; Box 1). Today, traditional farms, as well as MTF (of Type 1 or 3 ), contribute evenly to the exclusive production of Rainbow Trout. Some traditional farms have specialised in eyed eggs, producing 90 million eggs

This article is protected by copyright. All rights reserved. 
annually, which are sold worldwide. The development, refinement and implementation of recirculating aquaculture systems (RAS) has opened up for the construction of new enclosed facilities farming other high value species such as Pike-perch Sander lucioperca (700 tons annually), Yellowtail Kingfish Seriola Ialandi (1,200 tons annually), and Atlantic Salmon Salmo salar (2,000 tons annually). The latter two are species that have only been farmed in Denmark for a few years. In addition to land-based facilities, production also occurs at sea in cages. The annual production of Rainbow Trout reared at sea is 10,100 tons (2016). In cage culture, fish are grown from an initial mass of $\sim 1 \mathrm{~kg}$ to $5 \mathrm{~kg}$, predominantly for the production of roe, or trout caviar, which is a highly prized product.

Aquaculture production has given rise to a number of secondary industries, most notably feed manufacturers and equipment suppliers. Denmark has 50 years of tradition in the manufacture of aquaculture feed and today companies such as BioMar and Aller Aqua are globally among the largest aqua feed manufacturers, with production facilities worldwide, for cold and warm water species, in fresh and marine waters. Danish suppliers of aquaculture technology and turnkey facilities have also emerged successfully, many of which also operate globally.

\section{Environmental Impact and Regulations}

Today the concern over the environmental impact of aquaculture weighs heavy among the public and legislative authorities in Denmark, and aquaculture activities are strictly regulated. Sea cage farming is subject to environmental approval before it can be established, changed, or expanded. Establishing sea cages requires habitat impact studies, and environmental impact assessment studies, a responsibility that lies with the municipalities. The Environmental Protection Agency handles all matters related to placement of cages, and is the regulatory body, which determines the limit for nutrient releases to recipient waters with reference to the Water and Marine Strategy Framework Directives (Directive 2008/56/EC).

This article is protected by copyright. All rights reserved. 
The regulatory legislation of land-based aquaculture facilities has seen a large change in recent years; most notably there has been a transition of the MTFs operating under an annual feed allowance to an emission-based allowance based on the results from the pioneering work of the MTF initiative (Box 1).

\section{COMMERCIAL FISHERIES}

Danish commercial fishing has a long history but developed especially after World War II, where a new industrial fishing sector appeared. Atlantic Herring Clupea harengus was initially the focus species, but later a switch occurred towards industrial species, such as Sprat Sprattus sprattus, Norway Pout Trisopterus esmarkii and Lesser Sandeel Ammodytes marinus (Gislason et al. 2014). At the same time, Atlantic Cod Gadus morhua fishing grew markedly and Danish fishing had a golden period from 1978 to 1997, with yearly landings of fish and shellfish between 1.4 and 1.9 million tons. Since the late 1990s, however, total Danish landings have dropped substantially, mainly due to a decline in the sandeel stock. The reason for this decline is not known, but for this and other fisheries, such as cod, stock declines are usually associated with excessive fishing mortalities and/or declining stock productivity due to changing environmental conditions (ICES 2017). In recent years, fisheries management and the structure of fisheries have also changed fundamentally. There has been increasing control over fishing effort at the European level and in Denmark distribution of national quotas through marketable vessel shares (a variant of individually transferable quotas [ITQs]) was introduced in 2007 (Ministry of Environment and Food of Denmark 2015), leading to a substantial reduction in fleet capacity (Table 1). In addition, since the 1990s, buy-back schemes financed by the European Union (EU) have assisted in reducing the capacity of the European fishing fleets, including Danish vessels (Eigaard et al. 2014).

This article is protected by copyright. All rights reserved. 
Today the commercial Danish fishery for marine species occurs primarily in the North Sea, Skagerrak, Kattegat, and the Baltic Sea (Figure 1). There are also some Danish fishing efforts for herring in the Norwegian Sea, for Horse Mackerel Trachurus trachurus in the Western part of the English Channel and for Blue Whiting Micromesistius poutassou and Boarfish Capros aper in the waters west of Ireland. A total of 907,529 metric tons were landed in the primary waters of the Danish commercial fleet in 2017, mainly from the southwestern North Sea and the Skagerrak (Figure 1). These two areas have provided large catches throughout the period examined (1987-2017), whereas catches from the northern North Sea have decreased substantially. The quite substantial landings indicated for some coastal areas are largely comprised of blue mussels Mytilus edulis. In this paper, the Danish commercial fishery is defined as all fishing activity with vessels listed in the Danish Fisheries Agency's vessel register (Danish Fisheries Agency 2019a).

\section{Landing Compositions; Past and Present}

The Danish commercial fishery can be characterised by its landings composition (Figure 2), which demonstrates that there are in essence three major fleet categories: (1) fisheries for industrial fish species (Sprat, sandeel and Norway Pout), (2) fisheries for pelagic human consumption fish species (herring and Atlantic Mackerel Scomber scombrus), and (3) fisheries for demersal human consumption fish species (cod, European Plaice Pleuronectes platessa) and shellfish species. Blue mussel fishing is exclusively the most important bivalve fishery and the main crustacean fisheries are for Norway lobster Nephrops Norwegicus, northern shrimp Pandalus borealis and brown shrimp Crangon Crangon. The two shrimp species are typically caught in single species fisheries and Norway lobster in mixed fisheries together with species like cod, plaice and Common Sole Solea solea. None of the crustaceans are landed in large volumes (Figure 2), but are important by virtue of their high value.

This article is protected by copyright. All rights reserved. 


\section{Effort Structure and Fleet segments; Past and Present}

The species targeted typically defines the type of fishing effort deployed, and this applies to the Danish commercial fleet. The industrial species, the pelagic human-consumption species and the high-value crustacean species are almost exclusively captured with towed gears and this is clearly reflected in the effort proportions of the different gear types (Figure 3), where trawls (bottom and pelagic) are by far the most dominant gear types in the Danish fishery measured in kilowatt days (kWdays). Fishing with passive gears like gill nets, long lines, and traps requires much less enginepower than fishing with towed gears (Suuronen et al. 2012). Consequently, the importance of passive gear efforts in relation to catch volumes is likely underestimated in a direct kW comparison. This is the case for species such as cod, plaice, and sole where a significant part of the catches is taken by gill nets. Overall, the combined information of catch and effort shows that pelagic trawling for mackerel and herring, bottom trawling for industrial species (sandeel and sprat), bottom trawling for human-consumption fish and shellfish species (cod, plaice, and Norway lobster), together with dredging for blue mussels, dominate the Danish fisheries. The observed decline in bottom trawler effort (Figure 3) coincides with the above-described combination of declining stocks and the introduction of EU buy-back schemes and Danish ITQs.

\section{Ecosystem Effects and Biological Sustainability of the Danish Marine Commercial Fishery}

In recent years, it has been widely recognised that fishing activity has wide ecosystem impacts that reach beyond influencing density and size structure of the targeted species. Likewise, commercial fisheries can have a number of negative side effects on the marine ecosystem, recently summarized and discussed for different fleet segments in Danish commercial fishery in Gislason et al. (2014). The summary points to bottom trawling for mixed fish and shellfish species having the largest relative environmental impact based on criteria such as poor energy efficiency, substantial seabed impact, and high rates of by-catches and discards of fish and shellfish (Table 2). Dredging for blue mussels is also considered to have very high negative impacts on seabed and associated

This article is protected by copyright. All rights reserved. 
organisms, but with little by-catch or discards, and intermediate energy efficiency. Pelagic trawling has (logically) no significant seabed impact and low relative fuel consumption and as such scores as the most environmentally friendly fishery. However, this assessment is somewhat hampered by the lack of information about the other impact factors because the pelagic fishery has no observerbased monitoring program. Likely by-catch and discards are low in this fishery, but by-catch of seabirds and marine mammals could pose a problem. A similar assessment applies for the industrial trawl fisheries for sandeel and sprat (which are towing large pelagic-style trawls across the seabed) apart from a moderate benthic impact. Passive gears generally have better energy efficiency than towed gears, measured as energy consumption per landed unit of value. Gill nets may have significant by-catches of harbour porpoises Phocoena phocoena and sea birds, but the current extent in Danish fishery is poorly quantified. Since 1987 the proportion of total Danish fishing effort conducted with bottom trawls has declined markedly and steadily (Figure 3), reflecting a trend towards fisheries with lower ecosystem side effects. Removal of target species also affects food supplies for other predators and species interactions in the marine food web and these indirect effects are increasingly recognized in European fisheries management with efforts to integrate multispecies and food web models in population assessments and catch advice (ICES 2018).

\section{RECREATIONAL FISHERIES}

Recreational fishing has a long tradition in Denmark. The first angling clubs date back to circa 1870 when angling was considered a peculiar hobby, almost exclusively for the male upper class. In contrast, if common people angled for fish, they most likely did it for sustenance rather than for leisure. With a general increase in prosperity and spare time for the population from around 1900 , angling became more widespread as a hobby, the number of local clubs increased and in 1926, the Danish Angler Association was founded. Today recreational fisheries in freshwater and marine waters engages $12-17 \%$ of the population (Kroman et al. 2010).

This article is protected by copyright. All rights reserved. 
In saltwater, recreational fishing is practiced using stationary gear (e.g., gill and fyke nets), angling (rod and line) and spear fishing ( $<5 \%$ of the national license holders). Angling is by far the dominant type of fishery and especially coastal angling by wading (e.g., spin and fly fishing) is very widespread. This fishery targets primarily sea-run Brown Trout Salmo trutta, in addition to seasonal species such as Garfish Belone belone and mackerel. Other popular species targeted from various platforms (e.g., the shore, piers, private boats, and charter boats) are cod, herring, and different species of flatfish (Kroman et al. 2010). Moreover, specialized types of angling such as open water trolling for Atlantic Salmon and fly fishing/jig/trolling fishing for Northern Pike Esox lucius in nearshore areas, primarily in the Baltic Sea, is also popular. In saltwater, a small proportion of recreational fisheries is practiced with stationary gear such as gill nets, fyke nets, and pound nets. This fishery targets primarily European Eel and European Glounder Platichthys flesus.

In freshwater, recreational fisheries are almost exclusively practiced by angling, as spearfishing is prohibited and only very few, primarily landowners, use stationary gear. Potentially, anglers can fish in $~ 30,000 \mathrm{~km}$ of privately owned streams and 45,000 ha of lakes (fishing rights; $25 \%$ [area] state owned and $75 \%$ private owned) with an individual size up to 4056 ha, but access is not granted to all of these (Rasmussen and Hansen 2001). The primary target species in lakes are pike, perch, pikeperch, carp, and, to a lesser extent, eels and coarse fish species such as Roach Rutillus rutillus and bream. In addition, put-and-take fisheries for primarily Rainbow Trout are popular, but species like Brook Trout Salvelinus fontinalis, Arctic Char Salvelinus alpinus and sturgeon Acipenser spp. are also available in these artificial fishing lakes. Depending on geographic region, species such as sea/Brown Trout, salmon, Rainbow Trout, pike and perch are the primary target fish for fly fishing, spin fishing, and/or baited fishing in streams (Kroman et al. 2010; Figure 4).

This article is protected by copyright. All rights reserved. 


\section{Management of Recreational Fisheries in Denmark}

Since 1993 an annual national license fee has been mandatory for all anglers and spearfishers (aged 18-65) and recreational net gear fishers (aged 12 and up) fishing in inland and marine waters. Exceptions to this are adjoining landowners in freshwater, who can fish without license from their own land. Also, angling in designated put-and-take lakes requires no national license. In addition to the national license, recreational fishing in freshwater requires a permission from the landowner, which sometimes is facilitated through memberships of fishing clubs (Rasmussen and Pedersen 2018). In 2016 anglers/spearfishers purchased 140,000 annual, 21,000 weekly, and 30,000 daily licenses. In addition, 31,000 persons purchased the recreational net gear-fishing license. In 2017 the expected total revenue was 41 milion DKK (US\$6.4 million), which is used for (1) information, administration, and inspection activities (12.7\%), (2) management actions such as stocking (34.9\%) and habitat restoration in streams and lakes (25.6\%), and (3) research aimed to improve recreational fisheries management ( $26.8 \%)$.

\section{Regulations}

Various mandatory input regulations (e.g., closed areas, closed seasons, gear restrictions) and output regulations (e.g., minimum length limit, daily and annual bag limits, quotas) are used on a national and regional level. In addition, in freshwater, voluntarily regulations are often introduced at local levels (i.e., in fishing club waters). Voluntary catch and release fishing has grown in popularity in recent years (e.g., Jansen et al. 2011) especially among anglers fishing for seatrout, pike, and perch where release proportions can be up to $95 \%$.

\section{Habitat restoration and stocking}

Over the years, stocking of various fish species to boost recreational fisheries has occurred. Historically, and still today, trout is by far the most frequently stocked fish in Danish waters (Figure 5). Trout stockings are based on site-specific electrofishing monitoring programs, which produce local stocking plans that stipulate the genetic origin, age, and size of the stocking material. In recent

This article is protected by copyright. All rights reserved. 
years there has been a trend in the management of especially Brown Trout and salmon stocks to focus on habitat restoration rather than stocking as a management tool, (e.g., in some cases, local angler associations actually request that funds for stocking are converted into restoration projects). The trend is reflected by a clear decrease in the number of stocked Brown Trout in Danish waters between 2000 and 2017 (Figure 5). The management trend towards increasing habitat restoration initiatives is most profound in streams (e.g., restoring of spawning areas and removal of migration obstacles). Restoration projects specifically aimed at improving fish stocks other than Brown Trout and salmon are still quite rare and not least in lakes and marine areas.

\section{FUTURE PERSPECTIVES}

Globally, aquaculture production supplies some $50 \%$ of the fish for human consumption, and aquaculture is the fastest growing sector in the production of animal protein. Despite a large global growth, Danish aquaculture has experienced a modest overall growth of $8 \%$ during the past 10 years, despite being a political goal for many years (Brogaard et al. 2017). There is no single explanation for this; but the combination of stricter regulations, site and water availability, farmed species, and capital costs, are likely contributors, and represent the challenges for the future of Danish aquaculture production. Currently, the technology is available for farming potentially any species in recirculating aquaculture systems (RAS) on land (Dalsgaard et al. 2013) and RAS represents a promising culture system for expanding Danish aquaculture. Increased production in cage culture is also a possibility, but cage sites must compete with recreational and other uses, have sufficient political backing, and must be positioned where the recipient has the carrying capacity for the released nutrients. On the other hand, the infrastructure required for RAS operations have much higher initial costs, compared to cage farming. In all likelihood, future focus will be on reducing the high capital costs of RAS, further improving inline and end-of-pipe water treatment technology to reduce, or ultimately eliminate, emissions of nitrogen and phosphorus, while looking offshore for

This article is protected by copyright. All rights reserved. 
future sites for expanding cage farming. Recent years have seen the appearance of marine RAS facilities, and such facilities are likely to make a larger contribution to future land-based farming of high value species.

Environmental sustainability is a key objective of the EU's Common Fisheries Policy, which is a goal generally supported by consumers, fishers, and managers (Fitzpatrick et al. 2017; Soma et al. 2018). This increasing environmental awareness is likely one of the drivers of the observed decreasing proportion of high-impact bottom trawling in the Danish fishery (Figure 3). Also, economic and social sustainability are key Common Fisheries Policy objectives and with the introduction of ITQs, the economic performance of the Danish fleet appears to have improved with fewer vessels, reduced effort, stable occupation, and increasing landing values (Table 1; Figure 3). Questions have, however, been raised if improved economic performance through quota concentration and capitalization may negatively influence social sustainability by preventing new fishers from entering the business (Dinesen et al. 2018). The observed increase in average age of occupational fishers and vessel owners (Table 1) gives some support to this concern. Partly in response to these negative social developments the "coastal fishery system" was introduced in 2017 (Ministry of Environment and Food of Denmark 2017), which earmarks a substantial proportion of the national quotas for smaller coastal vessels. With this new policy initiative, it is expected that in the future also social sustainability, together with environmental and economic sustainability, is secured and enhanced in Danish commercial fishery.

For recreational fisheries, we believe that fishers, stakeholders, and managers are turning towards a more conservation-minded attitude where habitat restoration rather than stocking will be in focus as a main measure to improve the fisheries. Moreover, we also foresee that (1) focus on the role of natural predators as competitors with the recreational fishers for the resource (e.g., cormorants, seals) will increase, (2) interest in socioeconomic and human dimension aspects (e.g., angler behavior antecedents and actual behavior) will increase, (3) focus on development of novel methods to collect data that can inform the sector (e.g., citizen science projects including mobile 
phone applications; e.g., Venturelli et al. 2017) will expand, and (4) inter-sectoral conflicts (e.g., between commercial fishers and recreational fishers) as well as intra-sectoral conflicts (e.g., between spearfishers and anglers) will continue to flourish.

\section{References}

Brogaard, M., J. S. Herring, P. V. Jensen, A. K. Andersen, M. L. Holm, and R. Nielsen. 2017. Danish aquaculture - growth, challenges, and employment. (In Danish). Danmarks Statistik, ISSN 2446-0354. Available: https://www.danskakvakultur.dk/media/16645/Dansk-Akvakulturvaekst-udfordringer-og-beskaeftigelse_juni2017.pdf. (November 2018).

Dahl, J. 1990. Inland fisheries trough the last 200 years. Writings from the Institute of History, University of Odense 39:49-62 (in Danish).

Dalsgaard, J., I. Lund, R. Thorarinsdottir, A. Drengstig, K. Arvonen, and P. B. Pedersen. 2013. Farming different species in RAS in Nordic countries: Current status and future perspectives. Aquaculture Engineering 53:2-13.

Danish Fisheries Agency. 2017. Yearbook of Fishery Statistics 2016. Danish Fisheries Agency, ISSN 0907-9238. Available: http://webfd.fd.dk/info/sjle3/aarbog/Fiskeristatistik_2016.pdf (May 2019)

Danish Fisheries Agency. 2019a. Landings and catch statistics. Available: https://fiskeristyrelsen.dk/fiskeristatistik/landings-og-fangststatistik/ (May 2019).

Danish Fisheries Agency. 2019b. Annual Reports on fishing fleet capacity 2013-2016. Danish Fishery Agency. Available: https://fiskeristyrelsen.dk/fiskeristatistik/publikationer/flaaderapport/ (May 2019)

Danish Fisheries Agency. 2019c. Age statistics from mainpage: https://fiskeristyrelsen.dk/fiskeristatistik/alders-og-beskaeftigelsesstatistik/ (May 2019)

This article is protected by copyright. All rights reserved. 
Dinesen, G. E., I. W. Rathje, M. Højrup, F. Bastardie, F. Larsen, T. K. Sørensen, E. Hoffmann, and O. R. Eigaard. 2018. Individual transferable quotas, does one size fit all? Sustainability analysis of an alternative model for quota allocation in a small-scale coastal fishery. Marine Policy $88: 23-31$

Eigaard, O. R., P. Marchal, H. Gislason, and A. D. Rijnsdorp. 2014. Technological development and fisheries management. Reviews in Fisheries Science and Aquaculture 22:156-174.

Enghoff, I. B., B. R. McKenzie, and E. E. Nielsen. 2007. The Danish fish fauna during the warm Atlantic period (ca. 7,000-3,900 BC): Forerunner of future changes?' Fisheries Research 85:285-298 FAO (Food and Agriculture Organization of the United Nations). 2011. Fishery and Aquaculture Country Profiles. Denmark. Country Profile Fact Sheets. In: FAO Fisheries and Aquaculture Department. Rome. Available:http://www.fao.org/fishery/facp/DNK/en (September 2018). Fitzpatrick, M., Maravelias, C. D., Eigaard, O. R., Hynes, S., and Reid, D. 2017. Fisher's preferences and trade-offs between management options. Fish and Fisheries 18:795-807.

Gislason, H., J. Dalskov, G.E. Dinesen, J. Egekvist, O. R. Eigaard, N. Jepsen, F. Larsen, L. K. Poulsen, T. K. Sørensen, and E. Hoffmann. 2014. Environmental impact and sustainability in Danish Commercial Fishing. Charlottenlund: National Institute of Aquatic Resources, Technical University of Denmark. DTU Aqua Report No. 279-2014. (in Danish)

Hoffmann, E. and F. Bregnballe. 2018. Aquaculture. Den Store Danske, Gyldendal (in Danish). Available: http://denstoredanske.dk/index.php?sideld=35070 (October 2018).

ICES (International Council for the Exploration of the Sea). 2017. Advice on fishing opportunities, catch, and effort. Greater North Sea Ecoregion. 2017. Available: https://www.ices.dk/sites/pub/Publication\%20Reports/Advice/2019/2019/usk.27.3a45b6a7 $-912 b . p d f$

ICES (International Council for the Exploration of the Sea). 2018. Report of the Working Group on Multispecies Assessment Methods (WGSAM), 15-19 October 2018, Paris.

This article is protected by copyright. All rights reserved. 
Jacobsen, L., S. Berg, and C. Skov. 2004. Management of lake fish populations and lake fisheries in Denmark: History and current status. Fisheries Management and Ecology 11:219-224.

Jansen, T., R. Arlinghaus, T. Als, and C. Skov. 2013. Voluntary angler logbooks reveal long-term changes in a lentic pike, Esox lucius, population. Fisheries Management and Ecology 20:125136.

Kromand, R., J. Jordal-Jørgensen, E. Roth, and A. Rønnest. 2010. Behavior, motives and preferences among Danish anglers. Ministry of Food, Agriculture and Fisheries (In Danish), 148 pp

Madsen, H.V. 1905. Ørredopdræt i damme. Kort praktisk vejledning for begyndere. V. Schønemanns Forlag, Nyborg, Denmark.

Ministry of Environment and Food of Denmark. 2015. Danish Fisheries regulation, appendix 1 for MOF regular part - question 47, 2015. Available: http://www.ft.dk/samling/20142/almdel/mof/spm/147/svar/1266220/1551221/index.htm (May 2019).

Ministry of Environment and Food of Denmark. 2017. Fishery: new regulation announcement has come into force. Available: http://lbst.dk/nyheder/nyhed/nyhed/fiskeri-nyreguleringsbekendtgoerelse-er-traadt-i-kraft/ (November 2018).

Rasmussen, G. and P. Geertz-Hansen. 2001. Fisheries management in inland and coastal waters in Denmark from 1987 to 1999. Fisheries Management and Ecology 8:311-322.

Rasmussen G and S. Pedersen. 2018. Sea Trout (Salmo trutta L.) in Denmark. Pages 483-521 in J. Lobón-Cerviá and N. Sanz, editors. Brown Trout: Biology, Ecology and Management, First Edition. John Wiley \& Sons Ltd., Frederiksberg, Denmark.

Soma, K., J. R. Nielsen, N. Papadopoulou, H. Polet, M. Zengin, C. J. Smith, O. R. Eigaard, A. Sala, S. Bonanomi, S. W. K. van den Burg, G. J. Piet, E. Buisman, and A. Gümüş. 2018. Stakeholder perceptions in fisheries management - Sectors with benthic impacts. Marine Policy 92:7385.

This article is protected by copyright. All rights reserved. 
Suuronen, P., F. Chopin, C. Glass, S. Løkkeborg,, Y. Matsushita, D. Queirolo, and D. Rihan. 2012. Low impact and fuel efficient fishing-looking beyond the horizon. Fisheries Research 119120:135-146.

Venturelli, P., K. Hyder, and C. Skov. 2017. Angler apps as a source of recreational fisheries data: opportunities, challenges, and proposed standards. Fish and Fisheries 18:578-595.

This article is protected by copyright. All rights reserved. 


\section{Boxes}

\section{Box 1}

\section{MTF solutions to sustainable freshwater aquaculture}

The Danish model trout farm (MTF) was an initiative to increase aquaculture sustainability undertaken in the early 2000s based on recommendations from an advisory committee on Danish freshwater aquaculture. Three classifications of the MTF were defined, type 1-3 (type 1 and 3 were implemented), differing predominantly in their degree of water intake, and average residence time, or in short, the degree of recirculation (Figure 1). The aim was to remove as much organic matter, nitrogen, and phosphorous as possible by implementation of water treatment technology and establishing plant lagoons as an end of pipe treatment. Type 1 facilities are approved for the annual production of $25-230$ tons of fish, while type 3 is for a production greater than 230 tons annually. Type 1 must maintain a recirculation degree of $70 \%$ or better, a total hydraulic retention time of $14 \mathrm{~h}$ in the raceways and plant lagoon, and limit their water intake to less than $7.5 \mathrm{l} / \mathrm{s}$ per 10 tons of feed. Type 3 MTFs operate under stricter conditions and must has a recirculation degree of 95\%, a hydraulic retention time of $54 \mathrm{~h}$, and a capped water use of $1.5 \mathrm{l} / \mathrm{s}$ per 10 tons feed. Both MTF types must be fitted with sludge depot, mechanical particle removal in the form of settling zones and microsieves with a mesh size no larger than $75 \mu \mathrm{m}$, and a plant lagoon of a specific size with a meandering flow profile. Furthermore, a MTF type 3 must be fitted with a biofilter with a surface area of $400 \mathrm{~m}^{2}$ per ton feed, and a specific ammonium turnover of no less than $0.15 \mathrm{~g} / \mathrm{m} / \mathrm{d}$. Overall, the MTFs are required to have a removal efficiency of $50 \%$ for total nitrogen, $65-70 \%$ for total phosphorous, and $75-85 \%$ for BOD.

This article is protected by copyright. All rights reserved. 


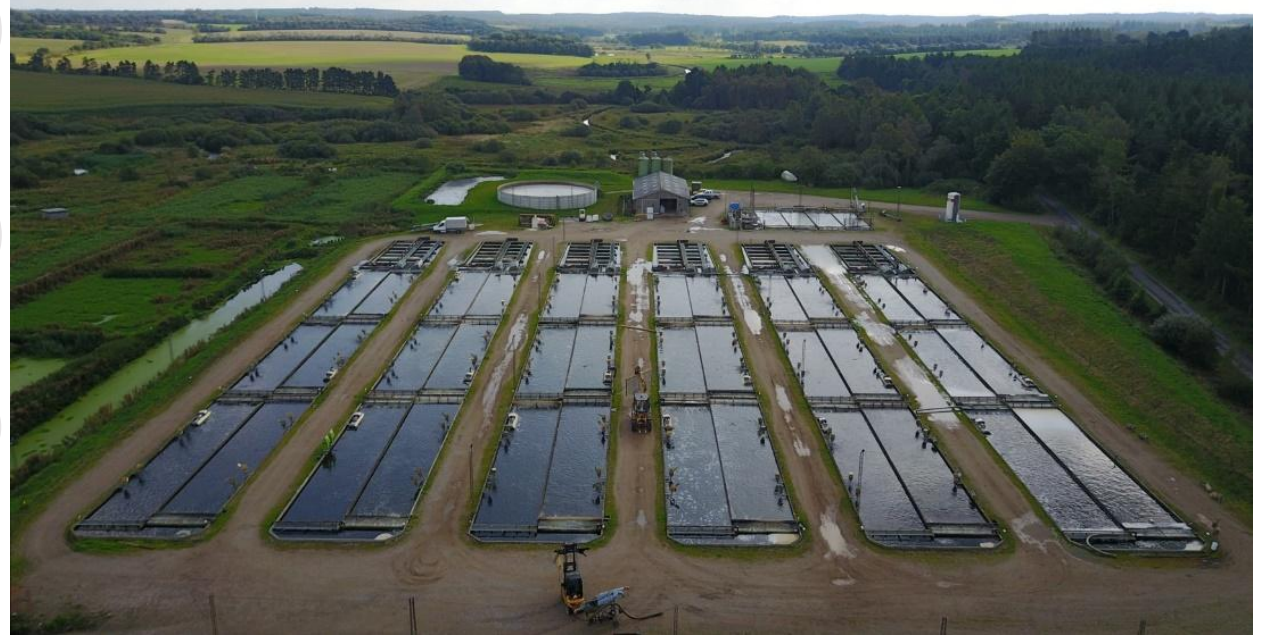

Box 1 picture: Aerial photograph of a Model Trout Farm type 3 located in the western part of Jutland. The farm was certified by the Aquaculture Steward Council in 2013. Each of the six individual raceways consists of six separated rearing units. Water is circulated through the facility by means of airlift pumps, and each unit is fitted with a drum filter and biological filter (far end of the picture). Feed is administered by means of pendulum feeders, which can be seen mounted along the sides of the rearing units. The sludge depot can be seen to the left (round tank), while the plant lagoons are visible to the left of the raceways. Photo: DTU Aqua.

This article is protected by copyright. All rights reserved. 


\section{BOX 2}

\section{COMMERCIAL FRESHWATER FISHERIES, A FADING TRADE}

Historically, Danish commercial inland fisheries have had a development with several stages. Around 300-400 years ago all fishing rights belonged to the monarchy or noble landowners who exploited the resource primarily as a source of food for the household, including the royal court. Fishing rights were, like hunting rights, considered very valuable and illegal fishing was severely punished. During this period, commercial fishing also took place, but the extent was minor. During the 19th century, many fishing rights were sold or given as privileges to civic citizens. The commercial use increased and with the construction of railroads export emerged as well (e.g., to the Hamburg fish market in Germany). Lakes were managed to generate the largest economic yield possible from fisheries and included management measures like stockings and introductions (Dahl 1990). In 1903, registration of catch was initiated by the state. These registrations show that one or a few fishers, often on a lease contract, managed most lakes. Eel was the most important species, both economically and by weight, annual catch 1930-1980 ca. 200 tons per year, perch 40 tons per year, pike 20 tons per year' and pikeperch 50 tons per year. The catch peaked in 1957 with a total of 1000 tons of fish caught. Around 1980, a decrease in eel catches started, followed by decreasing catch of other species partly due to a decreasing number of active fishers (Jacobsen et al. 2004). Today less than 10 fishers have a substantial part of their income from commercial freshwater fisheries; the mean annual yield during 2009-2018 is according to the official registration of landings $\sim 44$ tons, comprising 33\% eel, 37\% pikeperch, 11\% pike and 9\% perch. The development is foreseen to continue and might result in complete disappearance of this type of commercial fisheries in Denmark within a limited number of years.

This article is protected by copyright. All rights reserved. 
Tables

Table 1. Key statistics of the Danish Commercial fleet fishing in marine waters. The statistics are based on all vessels listed in the Danish Fisheries Agency's vessel register from 2007-2016 (Danish Fisheries Agency 2017). A number of these licensed vessels are inactive or fish only part time (yearly landing value less than $€ 36,000$ ) and for the years 2013-2016 data is also available for these fleet subsets (Danish Fisheries Agency 2019b). Age and occupational data for owners and employees is available for 2007-2016 from the Danish Fisheries Agency (2019c).

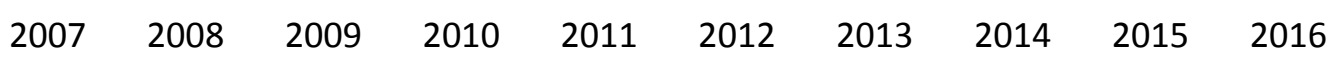

Total landings value of licensed fleet $(€ 1,000)$

Total fleet engine power $(\mathrm{kW})$

Total number of licensed vessels

Number of active vessels (landings $>€ 0$ )

Number of full time vessels (landings $>€ 36,000$ )

Total number of occupational fishers*

Average age of occupational fishers

Average age of vessel owners

45
362,646 341,203 294,754 393,105 422,817 392,595 403,233 389,056 453,317 488,828

$278,080264,992 \quad 248,025241,657233,967231,668224,215$ 226,111 220,913 211,550

2,826

2,816

2,780

2,737

2,627

2,442

2,365

$\begin{array}{llll}1640 & 1575 & 1500 & 1481\end{array}$

$\begin{array}{llll}600 & 566 & 541 & 551\end{array}$

4,606

$$
4,613 \quad 4,643
$$

4,675

4,713

4,685

4,769

$4,794 \quad 4,865$

4,866

46

47

47

48

49

49

50

51

53

54

54
55

* All owners and employees registered as full-time fishers in The Danish Fisheries Agency's register

This article is protected by copyright. All rights reserved. 
Table 2

Summary table of the direct negative environmental impact from different Danish commercial fleet segments based on an exposition of relevant international literature and Danish fisheries data (modified from Gislason et al. 2014). The summary is based on a relative gear-based and "all-other-things-equal" approach, which implies that some potential important factors, such as fishing intensity and extent of gear deployment, is not included in the assessment of impacts such as seabed impacts. In addition, only discard rates are considered in the different fleet segments, and not the total/absolute discards of each. With these methodological limitations in mind, the number of stars indicates the extent of the estimated impact - no effect = zero stars and strong negative effect $=$ five stars. A dash indicates that no information is available. Relative energy consumption indicates litres of diesel consumed relative to landing value. (See Table 7.1 in Gislason et al. 2014).

This article is protected by copyright. All rights reserved. 


\begin{tabular}{|c|c|c|c|c|c|c|c|}
\hline Fishery & $\begin{array}{l}\text { Relative energy } \\
\text { consumption }\end{array}$ & $\begin{array}{l}\text { Mechanical } \\
\text { seabed } \\
\text { (sediment) } \\
\text { impact }\end{array}$ & $\begin{array}{l}\text { Physical impact } \\
\text { on benthic } \\
\text { organisms }\end{array}$ & $\begin{array}{l}\text { By-catch of } \\
\text { fish and } \\
\text { shellfish }\end{array}$ & $\begin{array}{l}\text { By-catch of } \\
\text { marine } \\
\text { mammals }\end{array}$ & $\begin{array}{l}\text { By-catch of } \\
\text { seabirds }\end{array}$ & Discards \\
\hline $\begin{array}{l}\text { Pelagic trawling for } \\
\text { mackerel and } \\
\text { herring }\end{array}$ & $* *$ & & & - & - & - & - \\
\hline $\begin{array}{l}\text { Bottom trawling for } \\
\text { sandeel and sprat } \\
\text { Bottom trawling for }\end{array}$ & $* *$ & ** & ** & $*$ & & - & - \\
\hline $\begin{array}{l}\text { mixture of } \\
\text { Nephrops, cod, } \\
\text { plaice and sole }\end{array}$ & $* * * * *$ & *** & $* * *$ & $* * * *$ & & & $* * * *$ \\
\hline $\begin{array}{l}\text { Shellfish dredging } \\
\text { for blue mussels }\end{array}$ & $* * *$ & $* * * * *$ & $* * * * *$ & & & & \\
\hline $\begin{array}{l}\text { Gill net for cod, } \\
\text { plaice, sole, turbot } \\
\text { and lump sucker }\end{array}$ & $* *$ & * & * & $* *$ & ** & *** & * \\
\hline
\end{tabular}

This article is protected by copyright. All rights reserved. 


\section{Figure legends}

Figure 1. Distribution of Danish fish and shellfish landings in metric tons per ICES (International Council for the Exploration of the Sea) statistical rectangles (30x30 nautical mi) rectangle in 1987, 1997, 2007 and 2017 for logbook vessels (vessel length equal to or greater than $8 \mathrm{~m}$ in the Baltic Sea and $10 \mathrm{~m}$ in all other waters; based on data from the Danish Fisheries Agency). The blue line indicates the Danish Exclusive Economic Zone (EEZ) and the size of the circles reflects the relative landing amount in weight per square.

Figure 2. Total Danish landings of fish and shellfish, 1987-2017, for all licensed vessels (based on data from the Danish Fisheries Agency).

Figure 3. The total effort (kWdays) in Danish fisheries by major gear groups, 1987-2017 (based on data from the Danish Fisheries Agency).

Figure 4. Distribution of angling activity in Denmark based on different habitats and methods. Data have been obtained from a questionaire in which 1558 user panel respondents (response rate of 44\%) assigned themselves to different angling groups. Different colours indicate different types of angling within the habitat. Coast black $(\mathrm{bl})=$ angling by wading e.g., targetting sea trout and garfish; Coast light grey (lg) = angling from piers (e.g., targetting flatfish); Coast dark grey $(\mathrm{dg})$ = Surf casting; Lake $b \mathrm{l}=$ Predator angling targeting (e.g., pike, perch and pikeperch), Lake lg = baitfishing for coarse fish (e.g., carp, bream, and roach); Lake dg = Put and take fishing (e.g., Rainbow Trout), River bl = angling for seatrout and salmon; River lg = angling for other species (e.g., Rainbow Trout, pike and grayling); Sea bl = Trolling (e.g., for salmon); Sea Ig = Jigging (e.g., for Cod); Sea dg = Bait fishing (e.g., for flatfish); other types = types that could not be assigned the other groups. The figure is modified from table 8 in Kroman et al. 2010.

This article is protected by copyright. All rights reserved. 
Figure 5. Number of trout stocked in Denmark since 1987 at different age, size classes, and locations.

All stockings, except from "coastal stockings," have been conducted in freshwater.

This article is protected by copyright. All rights reserved. 
1987

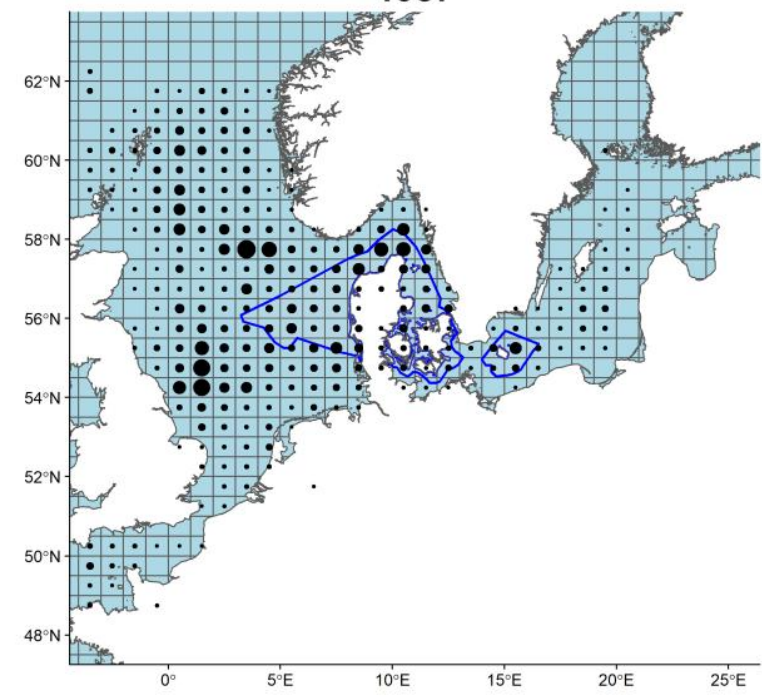

2007

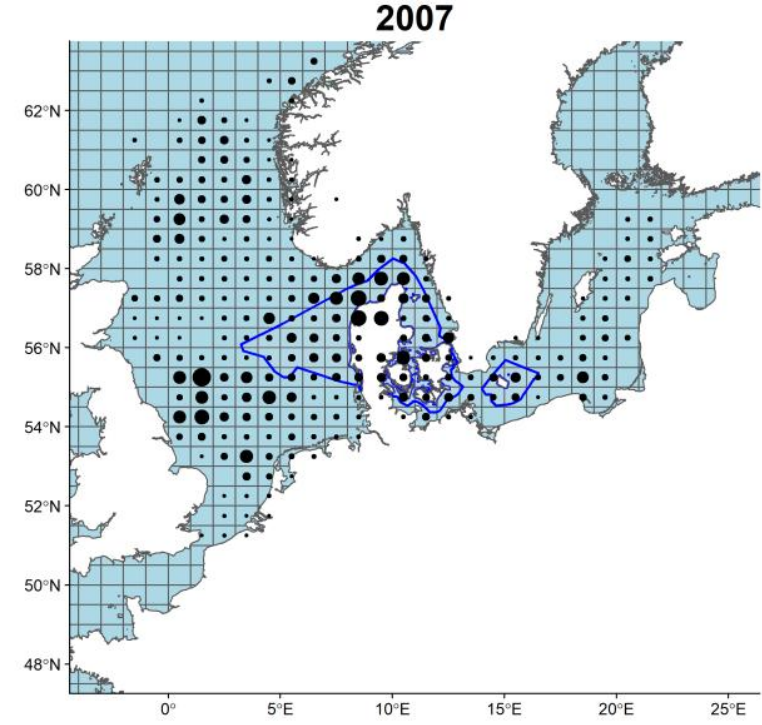

1997

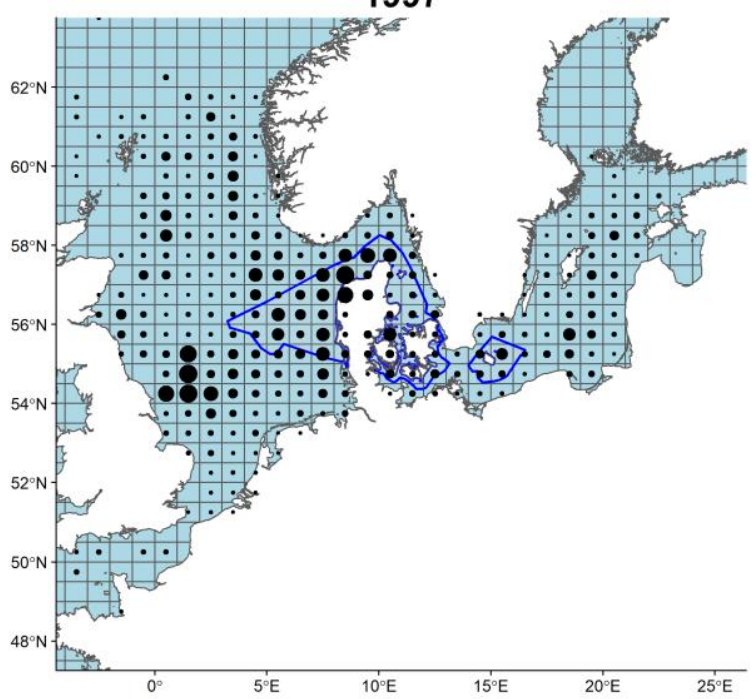

2017

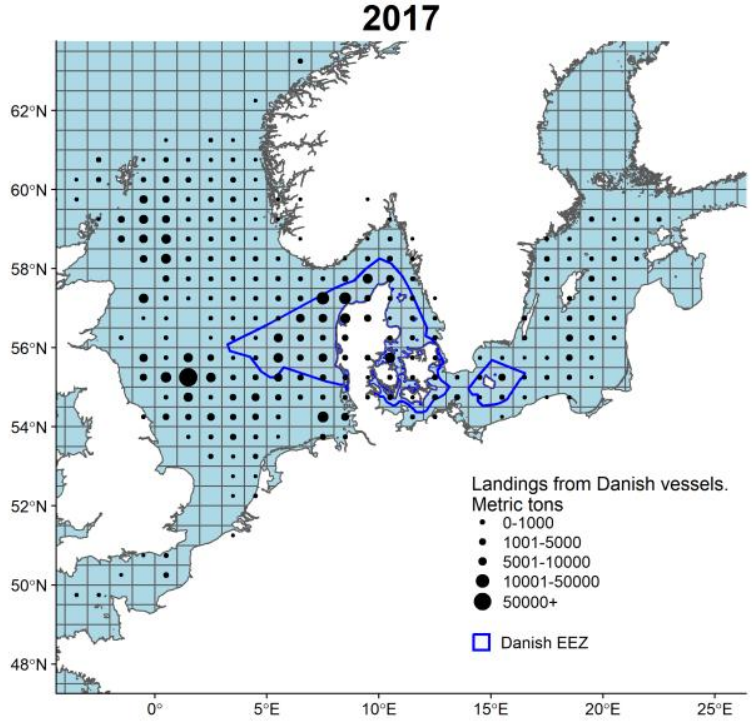

This article is protected by copyright. All rights reserved. 


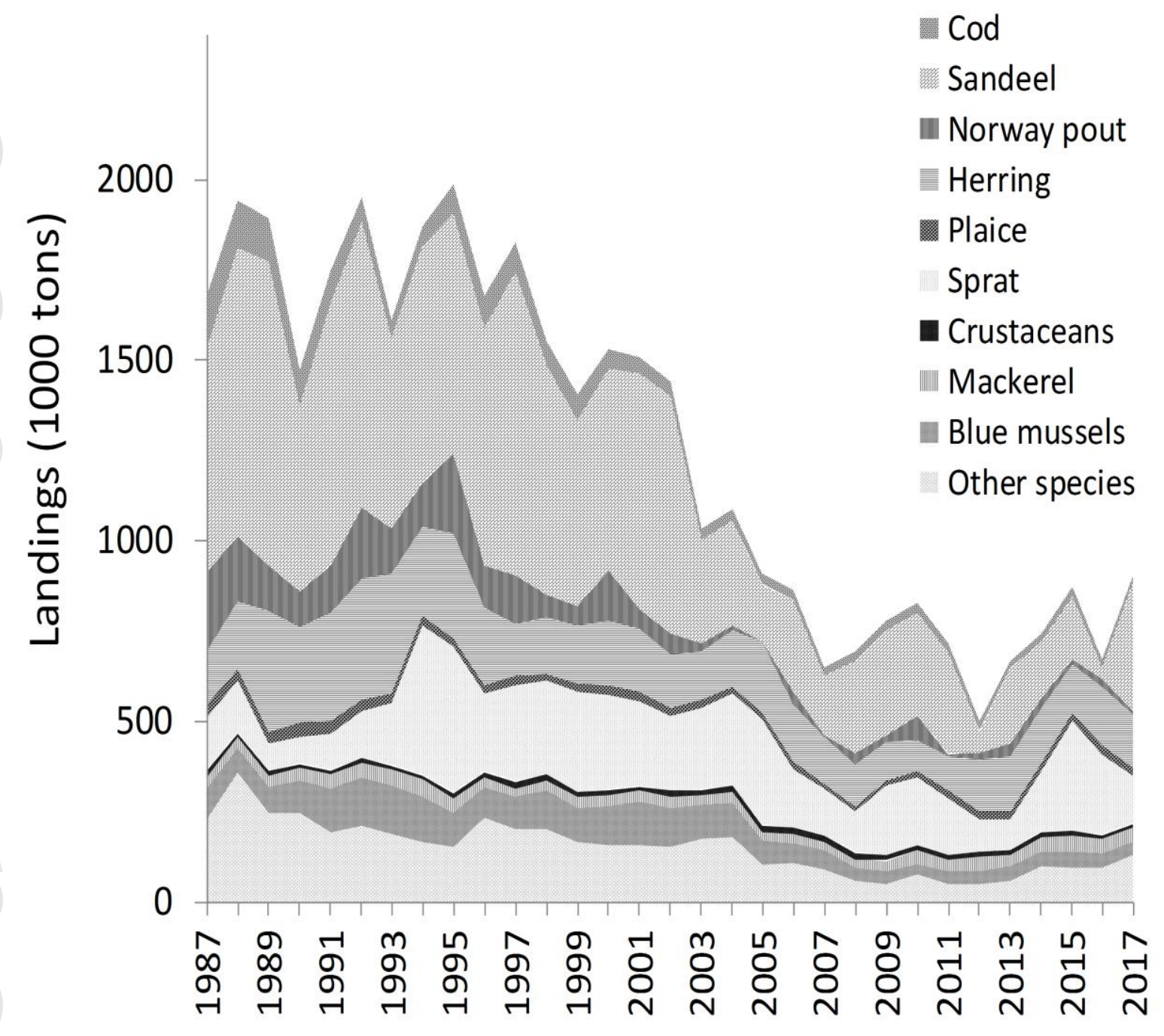

This article is protected by copyright. All rights reserved. 


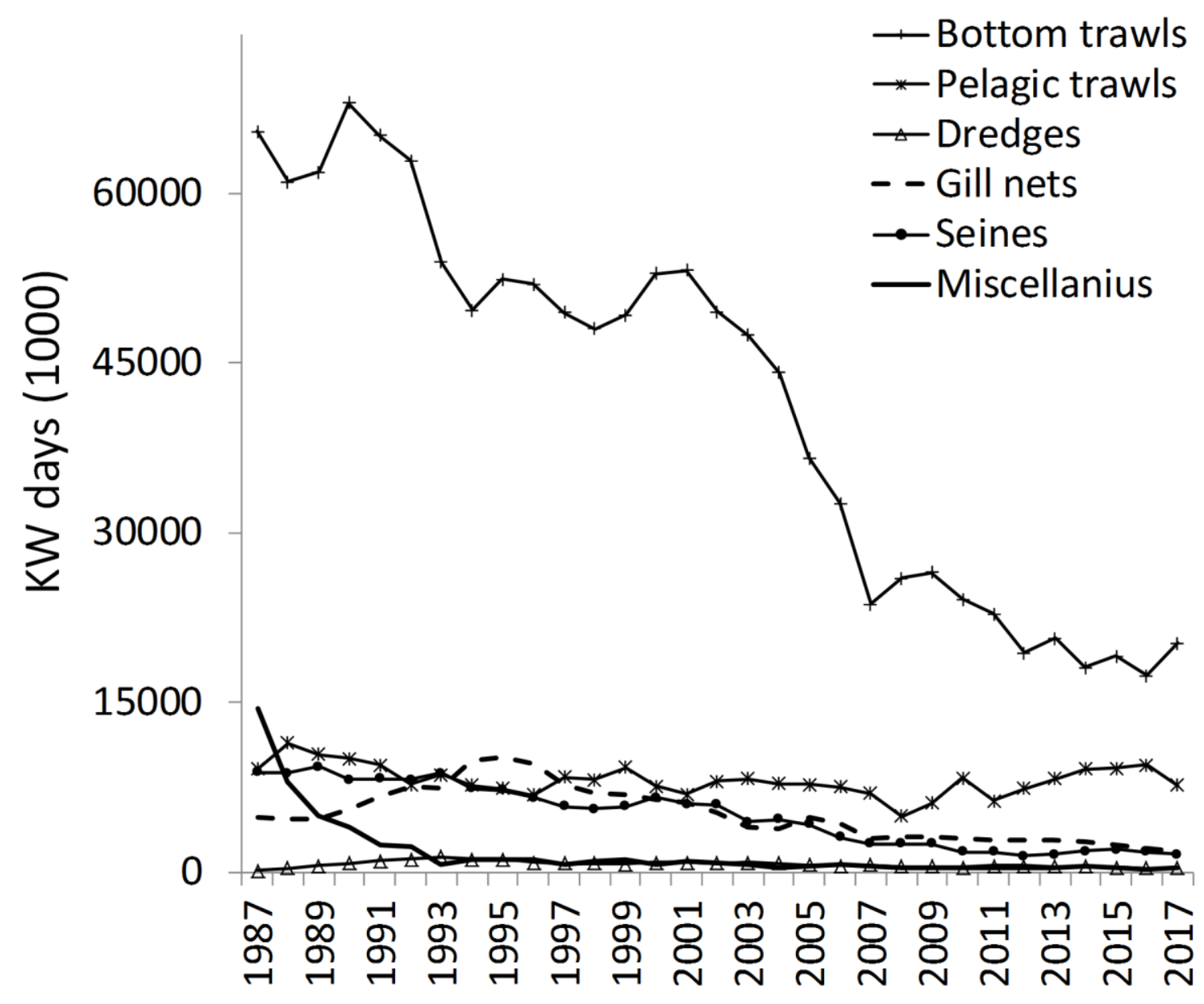

This article is protected by copyright. All rights reserved. 


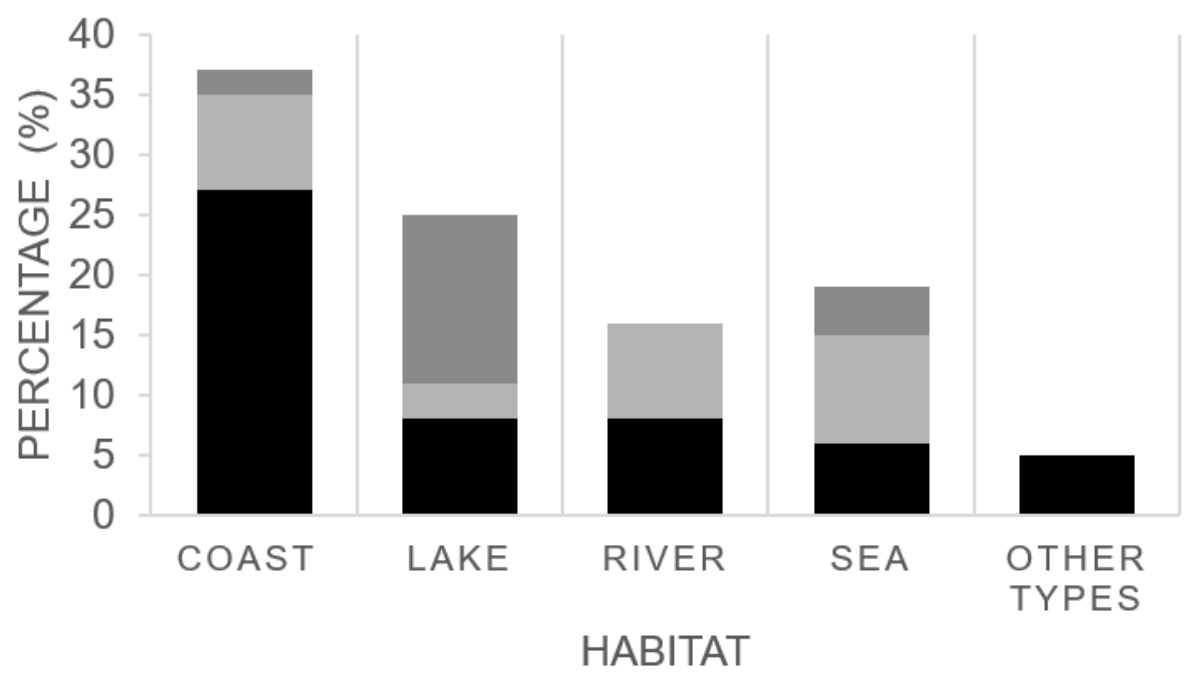

This article is protected by copyright. All rights reserved. 


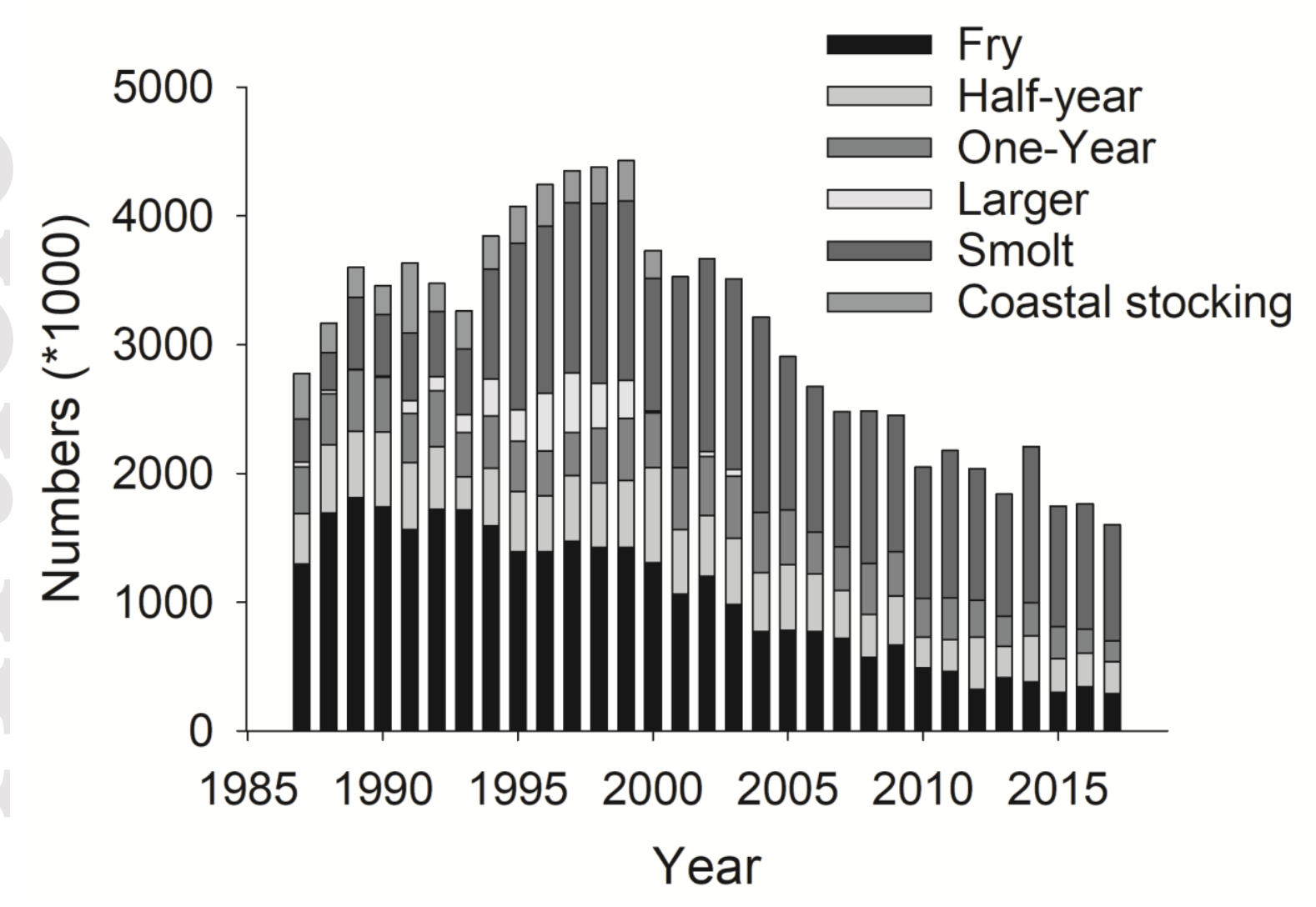

This article is protected by copyright. All rights reserved. 